\title{
Literatuuronderzoek ten behoeve van Caribisch Nederland. Push- en pullfactoren bij werving, selectie en behoud van leraren in afgelegen gebieden
}

Citation for published version (APA):

de Hoon, M., \& Cörvers, F. (2016). Literatuuronderzoek ten behoeve van Caribisch Nederland. Push- en pullfactoren bij werving, selectie en behoud van leraren in afgelegen gebieden. ROA. ROA Technical Reports No. 001 https://doi.org/10.26481/umarot.2016001

Document status and date:

Published: 01/03/2016

DOI:

10.26481/umarot.2016001

Document Version:

Publisher's PDF, also known as Version of record

Document license:

Other

Please check the document version of this publication:

- A submitted manuscript is the version of the article upon submission and before peer-review. There can be important differences between the submitted version and the official published version of record.

People interested in the research are advised to contact the author for the final version of the publication, or visit the DOI to the publisher's website.

- The final author version and the galley proof are versions of the publication after peer review.

- The final published version features the final layout of the paper including the volume, issue and page numbers.

Link to publication

\footnotetext{
General rights rights.

- You may freely distribute the URL identifying the publication in the public portal. please follow below link for the End User Agreement:

www.umlib.nl/taverne-license

Take down policy

If you believe that this document breaches copyright please contact us at:

repository@maastrichtuniversity.nl

providing details and we will investigate your claim.
}

Copyright and moral rights for the publications made accessible in the public portal are retained by the authors and/or other copyright owners and it is a condition of accessing publications that users recognise and abide by the legal requirements associated with these

- Users may download and print one copy of any publication from the public portal for the purpose of private study or research.

- You may not further distribute the material or use it for any profit-making activity or commercial gain

If the publication is distributed under the terms of Article 25fa of the Dutch Copyright Act, indicated by the "Taverne" license above, 
Literatuuronderzoek ten behoeve van Caribisch Nederland

\section{Push- en pullfactoren bij werving, selectie en behoud van leraren in afgelegen gebieden}

Marloes de Hoon

Frank Cörvers

\section{ROA Technical Report}

ROA-TR-2016/1

Researchcentrum voor Onderwijs en Arbeidsmarkt | ROA Research Centre for Education and the Labour Market | ROA 


\title{
Literatuuronderzoek ten behoeve van Caribisch
}

\section{Nederland}

\section{Push- en pullfactoren bij werving, selectie en behoud van leraren in afgelegen gebieden}

\author{
Marloes de Hoon \\ Frank Cörvers
}

ROA-TR-2016/1

March 2016

Research Centre for Education and the Labour Market Maastricht University

P.O. Box 616, 6200 MD Maastricht, The Netherlands

$\mathrm{T}+31433883647 \mathrm{~F}+31433884914$

secretary-roa-sbe@maastrichtuniversity.nl www.roa.nl 


\section{Inhoudsopgave}

Pagina

Voorwoord

1. Inleiding 1

2. Onderwijs- en arbeidsmarktschets van Caribisch Nederland 2

2.1 Kwaliteit van het onderwijs omhoog naar basiskwaliteit 2

2.2 Hoge geografische mobiliteit 3

2.3 Arbeidsparticipatie hoog op Bonaire en Sint Eustatius, laag op Saba 4

2.4 Moeizame personeelsvoorziening voor leraren 5

3. Theoretische achtergronden bij push- en pullfactoren van migratie 8

3.1 Neoklassiek en nieuw economisch model 8

$\begin{array}{ll}3.2 \text { Roltrapmodel } & 10\end{array}$

$\begin{array}{ll}3.3 \text { Netwerktheorie } & 10\end{array}$

$\begin{array}{ll}3.4 \text { Sociale cohesie en integratie } & 11\end{array}$

3.5 Samenvatting van theorieën over arbeidsmigratie met push- en pullfactoren 12

4. Werving, selectie en good practices voor de onderwijsarbeidsmarkt in afgelegen gebieden

4.1 Aantrekken en behouden van leraren: individuele en contextuele factoren 13

$\begin{array}{ll}4.2 \text { Beleidsinstrumenten } & 17\end{array}$

5. Conclusie 22

$\begin{array}{ll}\text { Referentielijst } & 25\end{array}$ 


\section{Voorwoord}

Dit literatuuronderzoek is uitgevoerd door het Researchcentrum voor Onderwijs en Arbeidsmarkt (ROA) in opdracht van Maestro Kompas. De auteurs danken Wim Didderen (Maestro Kompas) voor het mogelijk maken van het onderzoek. Voorts danken zij de medewerkers van het Maestro Kompas team van de Open Universiteit en Ardi Mommers (ROA) voor hun commentaar op een eerdere versie van dit rapport. 


\section{Inleiding}

Dit literatuuronderzoek beoogt bij te dragen aan het inzicht in de lerarenmarkt in Caribisch Nederland (CN). Er wordt verkend hoe men in afgelegen regio's en op kleine eilanden omgaat met de personeelsvoorziening (van leraren), met de dynamiek wat betreft in- en uitstroom op de (onderwijs)arbeidsmarkt en met de vaak relatief grote migratiestromen van en naar deze gebieden. Het doel van het literatuuronderzoek is om de push- en pullfactoren in beeld te krijgen die van belang zouden kunnen zijn voor de opleiding, de werving en het behoud van leraren op de BESeilanden (Bonaire, Sint Eustatius, Saba). Er wordt gekeken naar de achterliggende (theoretische) mechanismen voor arbeidsmigratie en de good practices in de personeelsvoorziening voor leraren en andere beroepsgroepen in min of meer geïsoleerde gebieden. In een vervolgonderzoek zal door interviews met (ervarings)deskundigen en enquêtes onder leraren worden nagegaan in welke mate de hier verworven inzichten werkelijk van toepassing zijn op de onderwijsarbeidsmarkt van de BESeilanden. In het vervolgonderzoek zal meer specifiek voor de BES-eilanden worden gekeken naar (i) de redenen waarom leraren komen en vertrekken, en (ii) het beleid dat er nu is om leraren aan te trekken om op de BES-eilanden te gaan werken, en de eventuele mogelijkheden voor verbetering.

Het literatuuronderzoek sluit aan op het vooronderzoek Onderwijsarbeidsmarkt en lerarenopleidingen in Caribisch Nederland (Cörvers, Claessen en Kluijfhout, 2015). Dat vooronderzoek geeft inzicht in vraag en aanbod op de onderwijsarbeidsmarkt van Caribisch Nederland, en behandelt enkele economische en geografische factoren die daarbij van belang zijn. Bovendien is in het vooronderzoek nagegaan hoe een duurzame regionale onderwijsinfrastructuur voor de BESeilanden kan worden opgezet. Voortbordurend op de eerdere bevindingen kan het literatuuronderzoek in dit rapport bijdragen aan het inzicht in de problematiek van de lerarenmarkt op eilanden zoals die in het Caribisch gebied.

Dit onderzoek begint in hoofdstuk 2 met een onderwijs- en arbeidsmarktschets van Caribisch Nederland, welke deels is gebaseerd op het reeds uitgevoerde vooronderzoek. In hoofdstuk 3 worden verschillende migratietheorieën besproken die een kader bieden voor het benaderen van de geografische dynamiek op de arbeidsmarkt voor leraren. Hoofdstuk 4 geeft een overzicht van een aantal good practices bij personeelsschaarste in het onderwijs (of andere beroepen/sectoren) in afgelegen gebieden. In hoofdstuk 5 volgen de conclusies. 


\section{Onderwijs- en arbeidsmarktschets van Caribisch Nederland}

Caribisch Nederland wordt gevormd door de zogeheten BES-eilanden: Bonaire, Sint Eustatius en Saba. De afstand tussen Nederland en de BES-eilanden is gemiddeld 7.200 kilometer; van Bonaire naar Saba en Sint Eustatius is het ruim 800 kilometer vliegen. Is het inwoneraantal van Bonaire met ca. 18.900 inwoners nog te vergelijken met een kleine Nederlandse gemeente, Sint Eustatius en Saba hebben met respectievelijk ca. 3.900 en 1.800 inwoners de omvang van een hele kleine deelgemeente of zelfs wijk of buurt van een gemeente in Nederland (CBS-cijfers per 1 januari 2015). De eilanden, die voorheen behoorden tot de Nederlandse Antillen, maken sinds 10 oktober 2010 als drie bijzondere gemeenten deel uit van Nederland. De wijziging was onderdeel van de staatkundige hervormingen binnen het Koninkrijk der Nederlanden, dat tot die tijd bestond uit Nederland, Aruba en de Nederlandse Antillen als onafhankelijke landen. Hiermee hielden de Nederlandse Antillen op te bestaan. Curaçao en Sint Maarten kregen, net als Aruba eerder in 1986, de status van een land binnen het Koninkrijk. De drie vormen samen de CAS-eilanden. Onderstaande paragrafen gaan in op de kwaliteit van het onderwijs, de (onderwijs)arbeidsmarkt en de arbeidsmigratie op de BESeilanden.

\subsection{Kwaliteit van het onderwijs omhoog naar basiskwaliteit}

Als bijzondere gemeenten vallen de BES-eilanden in de huidige situatie onder de Nederlandse weten regelgeving. Dit geldt ook voor het onderwijs, waardoor de minister van Onderwijs, Cultuur en Wetenschap (OCW) verantwoordelijk is voor het onderwijsbeleid op de BES-eilanden. Dit betekent dat de scholen in Caribisch Nederland deel uitmaken van het Nederlandse onderwijsstelsel. Er is een Improvement Programme (IP) ontwikkeld voor het primair en secundair onderwijs, met als doel het onderwijs op de BES-eilanden te verbeteren en de prestaties van leerlingen op te trekken naar Nederlandse standaarden voor kernvakken als taal (Nederlands) en wiskunde. De gevolgen hiervan zijn in het vooronderzoek beschreven (Cörvers et al., 2015). De kwaliteit van het onderwijs moet omhoog naar minimaal de basiskwaliteit, om uiteindelijk op het niveau van de Europees Nederlandse standaard te komen. De administratieve lastendruk zal toenemen door een uitbreiding van de verantwoording en monitoring die onvermijdelijk gepaard gaat met het streven naar een hogere kwaliteit. De streefdoelen en uit te voeren acties zijn in detail beschreven in de Onderwijsagenda voor Caribisch Nederland: samen werken aan kwaliteit (Ministerie van OCW, 2011). In het laatste rapport van de Inspectie van het Onderwijs (2014) wordt geconcludeerd dat er sprake is van vooruitgang, maar er nog een lange weg te gaan is voordat de kwaliteit van het onderwijs in Caribisch Nederland op het Europees Nederlandse niveau is.

Het onderwijs op de BES-eilanden is kleinschalig en zeer versnipperd in termen van taal, religie, pedagogische aanpak en etniciteit. Wat betreft de taal is deze versnippering heel duidelijk. Het onderwijs op Saba is geheel Engelstalig, zowel op de basisschool als op het voortgezet onderwijs. Ook wordt er in het Engels geëxamineerd. Nederlands wordt hier gegeven als vreemde taal. Op Sint Eustatius is bij de toetreding tot Nederland in $\mathbf{2 0 1 0}$ het Nederlands als instructietaal gehandhaafd om zo min mogelijk te wijzigen in de toenmalige situatie. ${ }^{1}$ In gesprekken met scholen, ouders en kinderen is echter gebleken dat Nederlands als instructietaal niet goed werkt. In juni 2014 is daarom

\footnotetext{
${ }^{1}$ https://www.rijksoverheid.nl/actueel/nieuws/2014/06/19/engels-wordt-enige-instructietaal-op-scholen-sinteustatius
} 
overeengekomen dat Engels de enige instructietaal wordt op alle scholen van Sint Eustatius. Dit betekent dat ook leraren voldoende kennis van de Engelse taal zullen moeten hebben. Leerlingen die na hun middelbareschoolopleiding in Nederland of op de Benedenwindse eilanden (Aruba, Bonaire, Curaçao) willen gaan studeren zullen bovendien intensief bijgespijkerd moeten worden wat betreft hun kennis van het Nederlands. Het is goed denkbaar dat dit leerlingen van Saba en Sint Eustatius belemmert om op Nederlandstalige (leraren)opleidingen op de Benedenwindse eilanden, in Nederland of in Suriname te gaan studeren.

Op Bonaire wordt het (beroeps)onderwijs in de praktijk gegeven in twee talen: het Nederlands en het Papiaments of Engels. Het lesmateriaal, de instructie en de examinering zijn officieel in het Nederlands. Veel leerlingen hebben in de praktijk echter Papiaments of Engels nodig om geïnstrueerd te worden, zelfs als Nederlands de officiële instructie- en examentaal is. Dit vraagt om specifieke bekwaamheden van leraren die vaak niet in de bevoegdheidseisen zijn terug te zien. Zo zijn ervaring en vaardigheden op het gebied van meertalig instrueren niet vereist voor het verkrijgen van lesbevoegdheid. Ook op andere sociaal-culturele aspecten zijn de scholen en leerlingen op de BES-eilanden zeer divers, bijvoorbeeld naar herkomst en religie. Bovendien zijn de personeelsbestanden van leraren zeer heterogeen wat betreft cultuur en professionele achtergrond (Onderwijsinspectie, 2014). In combinatie met de kleinschaligheid van de onderwijsarbeidsmarkt in Caribisch Nederland is het te verwachten dat het moeilijk is om leraren met bij de school aansluitende kenmerken (wat betreft achtergrond en bekwaamheid) aan te trekken.

\subsection{Hoge geografische mobiliteit}

De BES-eilanden kenmerken zich door een jaarlijkse, relatief omvangrijke immigratie en emigratie, waarbij er sprake is van netto immigratie (meer toestroom dan vertrek). Tabel 2.1 geeft voor de potentiële beroepsbevolking op de drie eilanden het geboorteland weer, dat wil zeggen iedereen tussen 15 en 75 jaar oud. De cijfers in de tabel laten zien dat op elk van de BES-eilanden het merendeel afkomstig is van een ander eiland of land. Het aandeel mensen dat elders is geboren, is met $72 \%$ het hoogst voor Saba. Voor Bonaire en Sint Eustatius is het aandeel dat geboren is op het eiland of in de eigen (Caribische) regio hoger (respectievelijk 62\% en 56\%). Een groot deel van de inwoners is geboren in een land buiten het Koninkrijk der Nederlanden. Voor Saba is dat meer dan de helft. Uit tabel 2.1 kan worden geconcludeerd dat het grootste deel van de populatie van de BESeilanden een migratieverleden heeft.

Tabel 2.1

Geboorteland op Caribisch Nederland, percentage van potentiële beroepsbevolking per eiland, 2014

\begin{tabular}{lrrr}
\hline & Bonaire & Sint Eustatius & Saba \\
& \% & $\%$ & $\%$ \\
\hline Op eiland waar men woont & 41 & 36 & 28 \\
Op ander BES-eiland, of Curaçao, Aruba, Sint Maarten & 21 & 20 & 11 \\
Nederland & 13 & 7 & 6 \\
Overige landen & 25 & 38 & 54 \\
\hline Totaal & 100 & 100 & 100 \\
\hline Totaal aantal inwoners & 14.456 & 3.251 & 1.517 \\
\hline
\end{tabular}

Bron: CBS Statline 
Migratiestromen van en naar de BES-eilanden resulteren onder andere in een opvallend grote mobiliteit van leraren op de BES-scholen: van de 302 po- en vo/mbo-leerkrachten in 2010 zijn er tussen september 2010 en september 2013121 (40\%) vertrokken. Daarnaast zijn er 188 (62\%) nieuwe leerkrachten aangesteld. In de komende jaren zal, naar verwachting, een instroom van gemiddeld 63 leraren per jaar nodig zijn om de baanopeningen in te vullen. Deze baanopeningen ontstaan voornamelijk door vervangingsvraag en minder door uitbreidingsvraag (Cörvers et al., 2015). Als er bovendien wordt verondersteld dat $80 \%$ van de leraren die nieuw aangesteld worden bevoegd is - gebaseerd op het percentage van onbevoegden in het zittende lerarenkorps - dan is het aantal onbevoegde leraren (voor bijscholing) gelijk aan ca. 13, (i.e. $20 \%$ van 63). Gezien de variatie rondom de trend over de afgelopen jaren kan dit aantal jaarlijks fluctueren van minder dan 5 tot bijna 20.

\subsection{Arbeidsparticipatie hoog op Bonaire en Sint Eustatius, laag op Saba}

De arbeidsmarkt in Caribisch Nederland verschilt op een aantal punten van Europees Nederland. Gemiddeld hebben Caribische Nederlanders in de leeftijd van 15 tot 75 jaar (i.e. de potentiële beroepsbevolking) vaker betaald werk en een voltijdbaan (CBS Statline, 2014a) dan Europese Nederlanders van dezelfde leeftijdscategorie. Figuur 2.1 geeft de arbeidsmarktpositie van de potentiële beroepsbevolking in Caribisch en Europees Nederland weer. Er is een groot verschil tussen enerzijds Bonaire en Sint Eustatius, waar respectievelijk $69 \%$ en $68 \%$ van de 15 - tot 75 -jarigen werkzaam is, i.e. de netto arbeidsparticipatie, en anderzijds Saba met $59 \%$ werkenden in de leeftijdscategorie van 15 tot 75 jaar. De lage arbeidsparticipatie op Saba hangt samen met het grote bevolkingsaandeel van veelal Amerikaanse studenten aan de Saba University School of Medicine.

Figuur 2.1

Positie op de arbeidsmarkt in Caribisch en Europees Nederland, percentage van totale potentiële beroepsbevolking, 2014

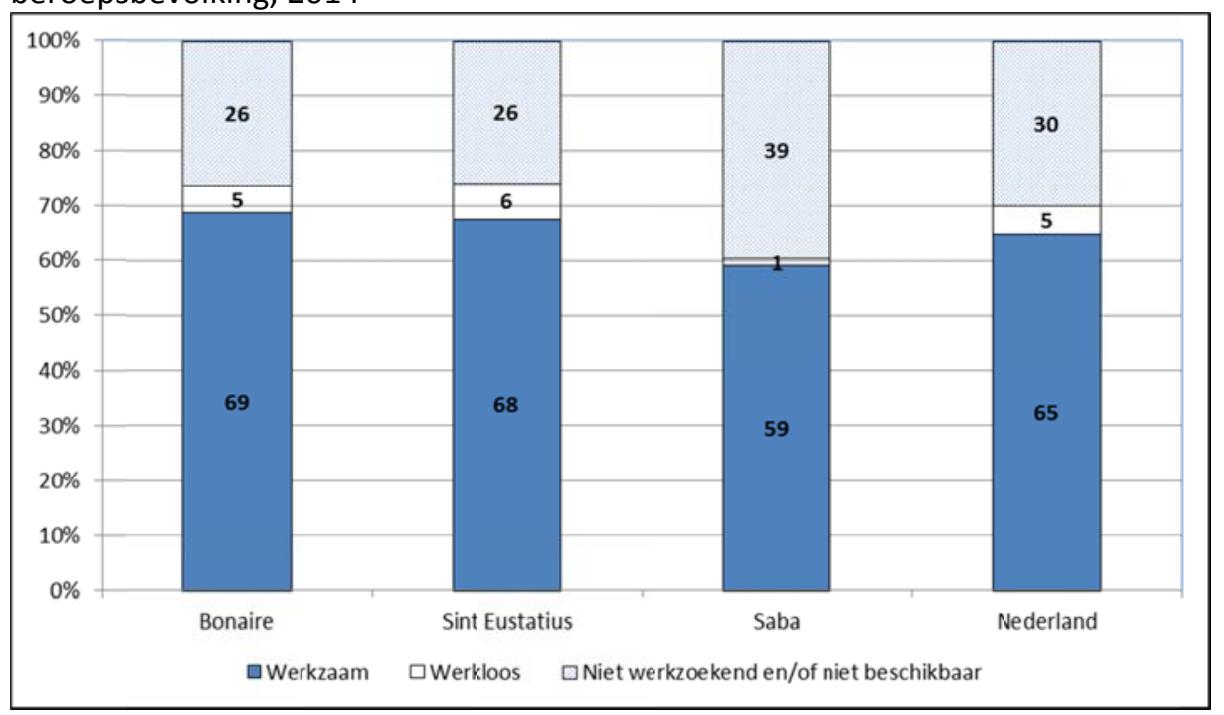

Bron: CBS Statline (2014b)

Ook in aantal gemeten uren is de arbeidsparticipatie hoog in Caribisch Nederland, want zowel mannen als vrouwen werken hoofdzakelijk voltijd. Op Saba werkt bijna $80 \%$ van de werkzame beroepsbevolking voltijd, op Bonaire en Sint Eustatius bijna $90 \%$. Dit is een groot verschil met 
Nederland, waar slechts de helft van de werkenden voltijd werkt en waar dit aandeel bovendien afneemt. De overheid, de bouw en de zorg zijn op elk van de eilanden belangrijke werkgevers. Op Bonaire is daarnaast de horeca een belangrijke sector. Op Sint Eustatius is ook de industrie een grote sector, dankzij het bedrijf NuStar, dat er een opslagterminal heeft. Op Saba werken veel mensen in het onderwijs, onder andere aan de eerder genoemde Amerikaanse medische universiteit.

De beroepsbevolking op de BES-eilanden wordt gekenmerkt door een grote groep van laagopgeleiden en door een grote verscheidenheid in herkomst en nationaliteit (Cörvers et al., 2015). Op Saba zijn er ten opzichte van Nederland veel hoog opgeleiden (hbo of wo), maar is bijna de helft van de inwoners laagopgeleid. Het aandeel middelbaar opgeleiden (havo/vwo/mbo niv. 2, 3 of 4 ) is op alle drie de eilanden beduidend lager dan in Nederland.

De arbeidsparticipatie van de verschillende herkomstgroepen loopt uiteen. Uit figuur 2.2 blijkt dat de netto arbeidsparticipatie (i.e. het percentage van de potentiële beroepsbevolking dat werkzaam is) van BES-inwoners die in Nederland zijn geboren op alle drie de eilanden hoger ligt dan de netto arbeidsparticipatie van de inwoners die op de BES- of CAS-eilanden zijn geboren. Op Bonaire is de netto arbeidsparticipatie van inwoners die elders zijn geboren het hoogst van alle herkomstgroepen, op Sint-Eustatius en Saba is de netto arbeidsparticipatie juist het laagst voor deze groep.

Figuur 2.2

Netto arbeidsparticipatie op Caribisch Nederland, percentage van potentiële beroepsbevolking per herkomstgroep, 2014

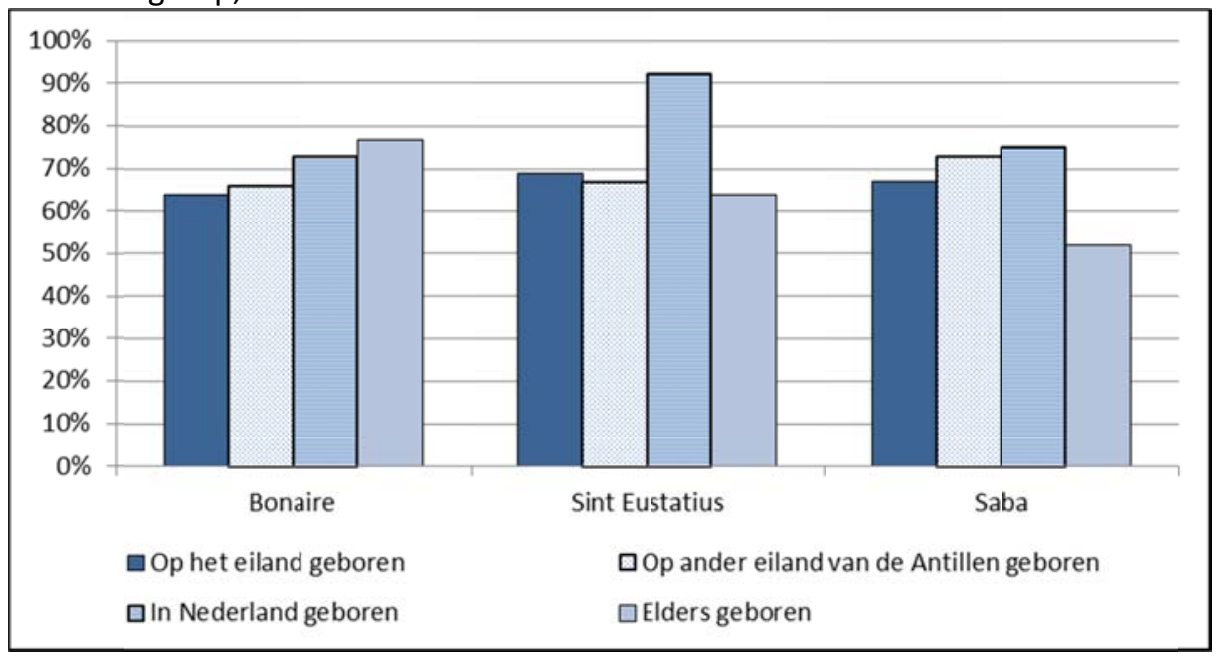

Bron: CBS Statline (2014b)

\subsection{Moeizame personeelsvoorziening voor leraren}

Op de BES-eilanden worden geen zelfstandige lerarenopleidingen aangeboden. Wel is er op Bonaire een dependance van de Universiteit van Curaçao voor de Lerarenopleiding Funderend Onderwijs (LOFO), en sinds 2013 ook voor de cursussen Pedagogisch Getuigschrift, Master Talen en Master Special Educational Needs. Het ligt niettemin voor de hand dat er voor de vacatures in het onderwijs op de BES-eilanden veel leraren worden geworven in Nederland, op de CAS-eilanden (Curaçao, Aruba en Sint Maarten), en breder in de Caribische regio. De leraren hebben dus zeer uiteenlopende opleidingsachtergronden. De verschillende diploma's die buiten Nederland zijn verkregen, moeten 
erkend worden door $\mathrm{Nuffic}^{2}$ om te kunnen spreken van een bevoegde leraar. Op 1 september 2013 was $78 \%$ van de leraren op de BES-eilanden bevoegd, $6 \%$ onbevoegd, $4 \%$ onbevoegd maar in opleiding, en voor $12 \%$ van de leraren was de bevoegdheid niet bekend (Cörvers et al., 2015). Hoewel er nu nog een overgangsregeling geldt voor de bevoegdheden van leraren, moeten alle leraren op termijn beschikken over een Nederlandse of daaraan gelijkgestelde bevoegdheid. De inschrijving in het lerarenregister (enkel mogelijk wanneer men bevoegd is) is voorlopig vrijwillig, maar zal in 2017 worden omgezet in een verplicht register. ${ }^{3}$

Door de grote rol die migratie uit diverse windhoeken speelt op de onderwijsarbeidsmarkt van de BES-eilanden, hebben leraren een heel diverse opleidingsachtergrond. Tabel 2.2 toont de verdeling van leraren naar het land waar zij hun diploma behaalden. Wat betreft het primair onderwijs (po) hebben de meeste leraren hun diploma behaald op de (voormalige) Nederlandse Antillen. Zij vormen samen een minderheid van de leraren basisonderwijs (43\%). Ruim een kwart van de leraren behaalde de onderwijsbevoegdheid in Europees Nederland. Voor het voortgezet onderwijs (vo) en middelbaar beroepsonderwijs ( $\mathrm{mbo}$ ) is dit aandeel echter veel groter; ruim zes op de tien leraren in het voortgezet onderwijs op de BES-eilanden heeft een lerarenopleiding voltooid in Europees Nederland. Een deel van deze leerkrachten is in Nederland geboren.

Tabel 2.2

Verdeling van leraren op de BES-eilanden naar land waar diploma behaald is, 2010

\begin{tabular}{lcc}
\hline Herkomst diploma's leraren & $\begin{array}{c}\text { po } \\
\text { \% }\end{array}$ & $\begin{array}{c}\text { vo/mbo } \\
\text { \% }\end{array}$ \\
\hline Nederlandse Antillen & 43 & 15 \\
Aruba & 5 & 1 \\
Nederland & 26 & 63 \\
Suriname & 13 & 11 \\
Verenigde Staten & 5 & 3 \\
Overig & 8 & 7 \\
Totaal & 100 & 100 \\
\hline
\end{tabular}

Opmerking: De percentages in de tabellen zijn op basis van de leraren waarvan de herkomst van het diploma bekend is. Van een aantal leraren is echter niet bekend waar zij hun diploma behaalden. Bron: Inspectie van het Onderwijs

De Inspectie van het Onderwijs (2014) concludeert dat de personeelsvoorziening van leraren in Caribisch Nederland problematisch is. "Onder leraren en in mindere mate ook onder schoolleiders is sprake van veel verloop en er zijn weinig mogelijkheden om lokaal geschikte opvolging te vinden. Leraren en schoolleiders die vanuit het Caribisch gebied of Nederland een aanstelling in Caribisch Nederland accepteren vertrekken in veel gevallen na enkele jaren weer. Dit komt de opbouw van een sterk en stabiel personeelsbestand niet ten goede. De personeelsbestanden zijn zeer heterogeen wat betreft cultuur en professionele achtergrond, wat de onderwijskundige aansturing compliceert." (p. 41) Het op structurele wijze inrichten van samenwerkingsverbanden tussen schoolinstellingen en -besturen uit Europees en Caribisch Nederland, bijvoorbeeld door de inzet van senior docenten, zou volgens de Inspectie van het Onderwijs de kwaliteit van het onderwijs ten

\footnotetext{
${ }^{2}$ Zie voor toelichting op de diplomawaardering https://www.nuffic.nl/diplomawaardering/overzichtenbuitenlandse-diplomas/overzicht-diplomas-curacao-sint-maarten-en-bes-eilanden.

${ }^{3}$ Zie de kamerbrief over de onderwijsarbeidsmarkt van staatssecretaris Dekker (OCW) van 28 oktober 2014 op http://www.rijksoverheid.nl/documenten-en-publicaties/kamerstukken/2014/10/28/kamerbrief-over-deonderwijsarbeidsmarkt.html.
} 
goede kunnen komen. Er zijn echter geen detacheringsregelingen die het onderwijspersoneel bij vertrek uit Nederland de verworven rechtspositie garandeert.

Degenen die vanuit Europees Nederland naar de CAS- en de BES-eilanden vertrekken om er gedurende langere tijd te wonen en/of werken blijven achter in de AOW-opbouw voor hun pensioenvoorziening. Ondanks dat de BES-landen als bijzondere gemeente deel uitmaken van Nederland, zullen leraren die vanuit Europees naar Caribisch Nederland vertrekken rekening moeten houden met dit zogeheten AOW-gat. Wel is het mogelijk om zich hiertegen vrijwillig te verzekeren. ${ }^{4}$ Voor medewerkers bij de overheid, in het onderwijs en in de zorg op de BES-eilanden is er sinds de staatskundige hervorming van 10 oktober 2010 een apart pensioenfonds opgericht, het Pensioenfonds Caribisch Nederland. Dit is de Caribische tegenhanger van het Europees Nederlandse ABP.

Voorts kunnen docenten die afkomstig zijn uit Europees Nederland bij verhuizing naar de BESeilanden om daar les te geven, doorgaans een vergoeding ontvangen voor de verhuiskosten en voor eventuele aanloopkosten in de woonlasten. Onder andere vanwege de hoge kosten voor verhuizing gaat de werkgever bij het verstrekken van de verhuisvergoeding vaak uit van een aanstelling van drie jaar. ${ }^{5}$ Als men binnen drie jaar vertrekt dan dient naar rato te worden terugbetaald.

\footnotetext{
${ }^{4}$ Voor AOW en pensioenen bij migratie zie de brochure van het Netwerk voor Organisaties van Oudere Migranten (NOOM): http://www.netwerknoom.nl/media/aow\%20en\%20pensioenen\%20informatie.pdf . Zie voor meer informatie over vrijwillige verzekeringen www.svb.nl/vv. De informatiebrochure van de Gwendoline van Puttenschool geeft een bondige weergave van de pensioenregelingen op Caribisch Nederland en de verhuisregelingen op Sint Eustatius: http://gvpschool.com/wp-content/uploads/Informatiebrochure-20142015-GvP-school-jan.-2014.pdf

${ }^{5}$ In het voortgezet onderwijs en middelbaar beroepsonderwijs op Saba zijn echter éénjarige contracten gangbaar.
} 


\section{Theoretische achtergronden bij push- en pullfactoren van migratie}

Het ontbreken van zelfstandige lerarenopleidingen en de hoge geografische mobiliteit van leraren van en naar de BES-eilanden, maakt het van belang om de arbeidsmigratie van leraren te bestuderen, en vanuit verschillende theorieën inzicht te verkrijgen in de beweegredenen om al dan niet te migreren. Arbeidsmigratie omvat hier zowel geografische mobiliteit tussen de eilanden als internationale mobiliteit, met het vinden van werk of het veranderen van baan als belangrijkste motief. In dit hoofdstuk wordt een viertal algemene theorieën over geografische mobiliteit en migratie gebruikt die zich in beginsel lenen om de arbeidsmigratie op Caribisch Nederland te verklaren. Er wordt aandacht besteed aan enerzijds pushfactoren (factoren met een afstotende werking), en pullfactoren (of: aantrekkingsfactoren) anderzijds. Bovendien wordt er onderscheid gemaakt tussen het micro- en macroniveau van migratiestromen.

\subsection{Neoklassiek en nieuw economisch model}

Neoklassiek economisch model van migratie

De meest bekende theorie gericht op de verklaring van migratie is het neoklassieke Harris-Todaro model. Het model leent zich ter verklaring van migratie op zowel micro- als macroniveau (Massey, 1998). Migratie resulteert volgens Harris en Todaro (1970) uit een op macroniveau onevenwichtige verdeling van arbeidsaanbod en productiefactoren (hoofzakelijk kapitaalgoederen, dat wil zeggen machines). In sommige landen en regio's zijn er arbeidskrachten in overvloed en zijn kapitaalgoederen schaars, waardoor het loonniveau laag ligt. Voor andere landen geldt het tegenovergestelde: overvloedig kapitaal, tekort aan arbeid en hoge lonen. Het resultaat is dat arbeiders zich bewegen van lagelonenlanden naar landen met hoge lonen.

Op microniveau stelt het neoklassieke economische model dat migratie het resultaat is van individuele beslissingen van rationeel handelende individuen. Volgens dit model handelen migranten rationeel en zullen zij besluiten te vertrekken van A naar B zodra zij verwachten hierdoor hun inkomen en/of overige arbeidsvoorwaarden te kunnen verhogen of hun bestaan te kunnen verbeteren (Harris en Todaro, 1970; Sjaastad, 1962). Individuen zijn dus op zoek naar plaatsen waar zij een (potentieel) voordeel halen (in termen van opbrengsten). Als er plaatsen zijn waar deze voordelen ten opzichte van de huidige locatie worden aangeboden, zal het individu migreren (Skeldon 1990). Hoewel binnen het neoklassiek migratiemodel in eerste instantie naar inkomensmaximalisatie van individuen werd gekeken, zijn er verschillende (recentere) onderzoeken waarin ook andere rechtspositionele zaken in beschouwing worden genomen. Zo zouden individuen ook status en imago van een beroep meenemen in hun afwegingen bij de keuze voor een baan elders. Bovendien blijken redenen om te migreren lang niet altijd werk-gerelateerd te zijn, maar is er ook sprake van 'softere' pullfactoren, zoals 'kwaliteit van leven' (zie bijvoorbeeld Williams en Sofranko, 1979).

In de brain drain literatuur wordt tevens gesteld dat de kans op het wegtrekken van hoogopgeleide jongeren positieve effecten kan hebben op het gemiddelde opleidingsniveau van de achterblijvers (zie voor een overzicht van mogelijke voordelen: UNDESA, 2004). De mogelijkheid om te migreren naar een land waar de inkomens hoger liggen, verhoogt immers het verwachte rendement op onderwijs en stimuleert derhalve individuen om te investeren in scholing en training (Beine et al., 
2008; Mountford, 1997; Stark et al., 1997). Ondanks dat een deel van de investeringen in het onderwijs door de brain drain niet direct ten goede komt aan het herkomstland (afgezien van bijvoorbeeld remittances, dat wil zeggen geldstortingen door migranten naar familie in hun herkomstland, en voordelige handelscontacten met het bestemmingsland), kan dus louter de kans op een goede baan in het buitenland al leiden tot hogere investeringen in onderwijs van de bevolking, en daarmee tot betere vooruitzichten op economische groei en een hoger gemiddeld welvaartspeil van de inwoners van het herkomstland.

\section{Nieuw economisch model van arbeidsmigratie}

Voorts is er een latere stroming in de migratieliteratuur waarbij migratie geen individuele beslissing is maar veeleer een uitkomst van beslissingen op een collectief niveau, waarbij het huishouden doorgaans als belangrijkste eenheid wordt gezien (Stark 1978). Volgens het nieuw economisch model $^{6}$ probeert een huishouden niet alleen het verwachte inkomen te maximaliseren, maar streeft het tevens naar een minimalisatie van de risico's. In ontwikkelde landen worden risico's voor het huishoudinkomen gereduceerd door bijvoorbeeld het sociale zekerheidsstelsel, overheidsprogramma's of particuliere verzekeraars.

\section{Toepassing van het neoklassiek en nieuw economisch model}

Op basis van het neoklassieke model kan worden verwacht dat mobiliteit van (bevoegde) leraren naar de BES-eilanden plaatsvindt wanneer:

1. Er een overschot is van leraren op andere eilanden (zoals Aruba of Curaçao) of landen (zoals Nederland).

2. De lonen voor leraren op de BES-eilanden relatief (ten opzichte van leraren in herkomstlanden) hoog liggen.

3. De (arbeids-)voorwaarden (anders dan loon) op de BES-eilanden aantrekkelijker zijn dan in herkomstlanden.

Naast deze factoren, die samenhangen met de verhouding tussen vraag en aanbod op de lerarenmarkt, zullen andere pull-factoren ('kwaliteit van leven') de aantrekkelijkheid van een baan in een specifiek land of specifieke regio vergroten en de migratiebereidheid doen toenemen. Vanuit het nieuw economisch model van arbeidsmigratie kan worden aangevuld dat een leraar bij de migratiebeslissing niet enkel naar individuele middelen en potentiële uitkomsten kijkt, maar ook in hoeverre binnen huishoudens overige middelen (van andere leden van het huishouden) kunnen worden ingezet om inkomensrisico's te minimaliseren. Denk hierbij bijvoorbeeld aan een (echt)paar bestaande uit een leraar en een arts als één van beiden al een baan op Caribisch Nederland heeft gevonden. De beslissing om daadwerkelijk te verhuizen kan er in deze situatie van afhangen of de ander al dan niet gelegenheid ziet om ook in Caribisch Nederland een baan te vinden. Wanneer deze mogelijkheden beperkt of afwezig zijn, zal de bereidheid van de leraar om met zijn of haar huishouden te migreren naar verwachting afnemen.

\footnotetext{
${ }^{6}$ In de literatuur wordt deze stroming aangeduid als NELM (New Economics of Labour Migration).
} 


\subsection{Roltrapmodel}

Vanuit het roltrapmodel is migratie te bezien als de beweging van (jonge) mensen van landelijke gebieden naar meer urbane regio's. Stedelijke gebieden kenmerken zich onder andere door goede kansen op de arbeidsmarkt (die andere regio's niet bieden) en bijgevolg maken werkenden in dergelijke gebieden sneller carrière dan in andere regio's. De roltrapregio-hypothese bestaat uit drie fases, zoals opgesteld door Fielding (1992):

Fase 1: Een roltrapregio trekt veel jonge mensen met 'groeipotentie' aan, die aan het begin van hun carrière staan (zij stappen op de roltrap).

Fase 2: Een roltrapregio biedt aan deze jonge migranten de kans om zich opwaarts te bewegen op de sociaal-economische ladder (de roltrap brengt hen naar boven).

Fase 3: Een roltrapregio verliest door emigratie een aanzienlijk aandeel van deze immigranten die remigreren op het moment van pensioneren of kort daarvoor (van de roltrap afstappen).

De hypothesen zoals opgesteld en getest door Fielding (1992) wordt op het punt van retourmigratie in verschillende studies slechts gedeeltelijk ondersteund. In overeenstemming met Fielding (1992) vinden onderzoekers voor verschillende geografische gebieden dat (jonge) mensen die migreren naar stedelijke gebieden (of roltrapgebieden) uiteindelijk terugkeren naar het gebied van herkomst (Conradson en Latham, 2005; Champion, 2012). Echter, in tegenstelling tot hetgeen verondersteld wordt met betrekking tot de derde fase, blijken de retourmigranten slechts een relatief korte periode van hun werkleven in de roltrapregio te hebben doorgebracht, en wachten zij in de minderheid van de gevallen tot hun pensioensleeftijd om terug te keren.

\section{Toepassing van het roltrapmodel}

Migratie van en terug naar de BES-eilanden volgens het roltrapmodel zou betekenen dat urbane regio's buiten de BES-eilanden dienen als roltrapgebied waar de BES-migranten worden opgeleid tot leraar of waar zij ervaring opdoen in het leraarschap. Hierdoor stijgen zij op de sociale ladder. Het is belangrijk inzicht te krijgen in de mate waarin dit werkelijk gebeurt en of men al dan niet terugkeert naar de BES-eilanden. Daarbij zou er ook inzicht moeten worden verkregen in de urbane gebieden waar men naar toe verhuist voor opleiding en eventueel werk - zoals steden in Nederland of op de CAS-eilanden, of steden in overige landen in het Caribisch gebied of Zuid-Amerika - en de redenen van terugkeer en de leeftijd waarop men terugkeert. Bestaand onderzoek voorziet niet in eenduidige antwoorden op deze vragen.

\subsection{Netwerktheorie}

In tegenstelling tot de neoklassieke migratietheorie - met de focus op het initiëren van migratie gaat de netwerktheorie in op het voortduren van de migratiestromen, waarbij de sociale netwerken een cruciale rol spelen. De netwerktheorie gaat uit van bestaande netwerken van migranten, voormalig migranten en niet-migranten in herkomst- en bestemmingslanden, welke de kans op internationale migratie vergroten doordat deze de kosten en risico's van migratie verlagen en de 
verwachte opbrengsten van migratie verhogen. Sociale netwerken zijn van belang in zowel het herkomstland als in (potentiële) bestemmingslanden.

In de netwerktheorie is het verband tussen migratie en sociale netwerken gebaseerd op wederzijdse beïnvloeding. Enerzijds wordt de omvang en richting van migratie beïnvloed door informatie, ideeën en middelen die zijn ingebed in netwerken bestaande uit familie, vrienden en buren in samenlevingen binnen herkomst- en bestemmingslanden. Anderzijds zorgt migratie voor het bouwen en transformeren van deze sociale netwerken (Brown, 2002). Een migrantennetwerk in een bestemmingsland voorziet derhalve individuele migranten van sociaal kapitaal, waarmee integratie kan worden bevorderd en de kans op retourmigratie mogelijk afneemt (zie ook paragraaf 3.4).

Recente literatuur laat echter ook zien dat migrantennetwerken niet noodzakelijkerwijs migratie bevorderen. Zo bestaat er een aantal feedback mechanismen vanuit de migrantengemeenschap, welke migratie kunnen ondermijnen op de (middel-)lange termijn. Bij een toenemende omvang van een migrantengemeenschap in een vestigingsland zou de kans van individuen of huishoudens om te migreren naar dat land in een omgekeerde U-vorm verlopen (Bauer et al., 2000; Epstein, 2008: 573), omdat de migranten die er al zijn (uit eigen belang) negatieve signalen kunnen afgeven. Migranten kunnen dus middels het delen van informatie potentiële migranten in het herkomstland doen besluiten niet te migreren, of een ander bestemmingsland te kiezen.

\section{Toepassing van de netwerktheorie}

De netwerkrelaties op de BES- en CAS-eilanden zijn erg complex, met vele culturele en historische achtergronden. Vanuit de netwerktheorie bezien gaat de diverse herkomst van de bevolking op de BES-eilanden gepaard met migrantennetwerken, die migratie naar en van een aantal specifieke landen (Nederland en de CAS-eilanden in het bijzonder) kan bevorderen. Immers, de verwachte kosten en risico's van migratie worden lager door de aanwezigheid van een migrantennetwerk van dezelfde herkomst als de betreffende migrant. Toch kunnen er ook negatieve signalen uitgaan van de migrantengemeenschap die de migratiestromen juist afremmen. De mate waarin netwerken migratie bevorderen of afremmen is dus niet eenduidig.

\subsection{Sociale cohesie en integratie}

De meeste theorieën omtrent integratie en assimilatie stellen dat hoe langer migranten blijven, des te meer zij geïntegreerd raken in de ontvangende samenleving, des te moeilijker het wordt om terug te keren en des te sterker zij geneigd zijn zich blijvend te vestigen (bijv. Dustmann, 2008; Haug). Hieraan gerelateerd is dat de wens om terug te keren afneemt wanneer sociale en economische banden met het land van herkomst afzwakken, en migranten in toenemende mate gericht zijn op het vestigingsland. Het idee van een negatieve samenhang tussen integratie in het vestigingsland en oriëntatie op het herkomstland valt binnen een bredere stroming van assimilatieonderzoek (zie bijvoorbeeld Castles en Miller, 2003).

\section{Toepassing van het integratiemodel}

In het kader van de integratie- en assimilatietheorieën kan worden gesteld dat economische en socioculturele integratie van leraren op de BES-eilanden de kans op terugkeer naar het land van herkomst verkleinen. Tegelijkertijd wordt de kans op terugkeer juist vergroot wanneer de sociale en economische banden met het herkomstland groter zijn. De causaliteit hiervan kan echter ook in de 
omgekeerde richting verlopen: migranten die reeds de intentie hebben om terug te keren zijn minder geneigd of genoodzaakt om te integreren in het land van bestemming en zijn sterker gemotiveerd om banden met het thuisland te behouden om terugkeer te vergemakkelijken.

\subsection{Samenvatting van theorieën over arbeidsmigratie met push- en pullfactoren}

Tabel 3.1 geeft een samenvattend overzicht met de belangrijkste push- en pullfactoren volgens de verschillende theorieën.

Tabel 3.1

Overzicht van migratie- en integratietheorieën met belangrijkste factoren

\begin{tabular}{|c|c|}
\hline Theorie & Belangrijkste push- en pullfactoren \\
\hline $\begin{array}{l}\text { Neoklassieke } \\
\text { economische } \\
\text { theorie }\end{array}$ & $\begin{array}{l}\text { Arbeidsmigratie, inclusief binnenlandse baanmobiliteit tussen regio's, is de uitkomst van } \\
\text { een individuele rationele afweging waarbij gestreefd wordt naar nutsmaximalisatie, i.e. } \\
\text { verwachte opbrengsten zo hoog mogelijk en verwachte kosten zo laag mogelijk: } \\
\text { - Arbeidsvoorwaarden - verschillen in beloning bewegen individuen richting landen of } \\
\text { beroepen met relatief hoge lonen en relatief gunstige secundaire } \\
\text { arbeidsvoorwaarden } \\
\text { - Status van het beroep - verschillen in status (van één beroep tussen landen of van } \\
\text { verschillende beroepen binnen een land) bewegen individuen richting landen of } \\
\text { beroepen met een relatief gunstige status } \\
\text { - Infrastructuur voor migranten (van dezelfde herkomst) - een bestaande } \\
\text { infrastructuur voor migranten reduceert de kosten van migratie en vergroot de kans } \\
\text { op migratie als uitkomst van een rationele afweging } \\
\text { Overige factoren - gunstige omstandigheden op zowel professioneel (bijv. HRM- } \\
\text { beleid van werkgever, collega's) als privégebied (bijv. woonomgeving) zullen de } \\
\text { opbrengsten van arbeidsmigratie vergroten en de relatieve kosten drukken }\end{array}$ \\
\hline $\begin{array}{l}\text { Nieuw } \\
\text { econon } \\
\text { model }\end{array}$ & $\begin{array}{l}\text { Arbeidsmigratie is de uitkomst van een beslissing op een collectief niveau, met het } \\
\text { huishouden als belangrijkste eenheid: } \\
\text { - Individuen streven naar een maximalisatie van het huishoudinkomen, i.e. inclusief het } \\
\text { inkomen van de partner } \\
\text { - Het inkomen van de partner als deel van het huishoudinkomen is ook van belang voor } \\
\text { de minimalisatie van de risico's verbonden aan arbeidsmigratie }\end{array}$ \\
\hline Rolt & $\begin{array}{l}\text { Nadruk op de levensloop als belangrijke factor in (arbeids-)migratie: } \\
\text { - Levensfase speelt als pushfactor op individueel niveau een grote rol in geografische } \\
\text { mobiliteit } \\
\text { - Kenmerken van een regio zijn pullfactoren, bijvoorbeeld de mogelijkheden voor } \\
\text { onderwijs en carrière in een roltrapregio, voorzieningen voor individu en familie }\end{array}$ \\
\hline Netv & $\begin{array}{l}\text { Sociale netwerken van migranten in herkomst- en bestemmingslanden bepalen de } \\
\text { migratiestromen: } \\
\text { - Informatie en positieve of negatieve signalen die gegeven worden door } \\
\text { migrantengemeenschap } \\
\text { - Sociaal kapitaal in de migrantengemeenschap kunnen kosten voor migrant verlagen, } \\
\text { en opbrengsten verhogen } \\
\text { - Veranderingen in migratiestromen dragen bij aan opbouw of terugloop van } \\
\text { netwerken }\end{array}$ \\
\hline $\begin{array}{l}\text { Sociale cohesie } \\
\text { en integratie }\end{array}$ & 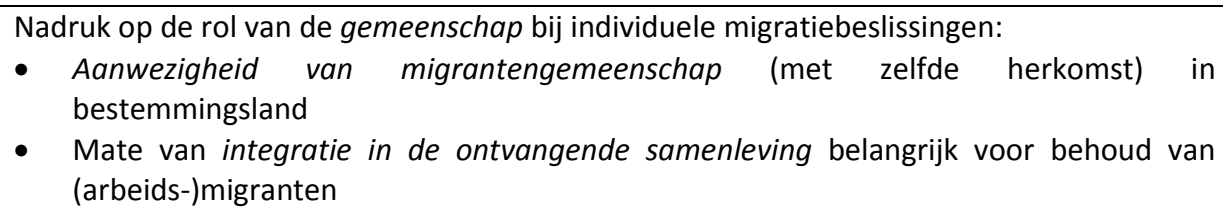 \\
\hline
\end{tabular}




\section{Werving, selectie en good practices voor de onderwijsarbeidsmarkt in afgelegen gebieden}

In dit hoofdstuk wordt in aanvulling op de algemene theoretische achtergronden over geografische mobiliteit en migratie in hoofdstuk 3, meer inzicht gegeven in de problematiek op de onderwijsarbeidsmarkt. Hierbij wordt gekeken naar factoren die van invloed zijn op het aantrekken en behouden van leraren, en vooral naar de manier waarop in dunbevolkte of afgelegen gebieden wordt omgegaan met krapte op de lerarenmarkt en de kwaliteit van het lerarenkorps. Hoewel de lerarenmarkt op de BES-eilanden zeer specifieke kenmerken heeft - onder andere wat betreft geografische, demografische en bestuurlijke factoren - kunnen studies naar vergelijkbare problematiek elders in de wereld waardevolle inzichten bieden bij het opzetten van een duurzame onderwijsinfrastructuur in Caribisch Nederland. Deze studies worden in paragraaf 4.1 besproken.

In de bestaande literatuur vinden we onder andere voorbeelden van knelpunten in de personeelsvoorziening van scholen in rurale gebieden van Australië (zie bijvoorbeeld Brasche en Harrington, 2012; Jorgensen et al., 2010; Lock et al., 2009), waar (Aboriginal)scholen moeilijkheden ondervinden bij het aantrekken van nieuwe leerkrachten. Bovendien hebben de scholen vaak te maken met een hoge teacher turnover, omdat de leraren die worden aangetrokken vaak na enkele jaren weer vertrekken. Om meer te weten te komen over de knelpunten in de personeelsvoorziening in afgelegen en/of rurale gebieden is er een aantal beleidsprogramma's ontwikkeld en geëvalueerd, waarvan in paragraaf 4.2 een bespreking volgt. Hierbij wordt met name gekeken naar landen met een min of meer vergelijkbare 'kleine-eilandenproblematiek' als in Caribisch Nederland. Cases die in dit hoofdstuk worden besproken zijn onder meer Indonesië en het Caribisch deel van het Brits Gemenebest, waaronder het kleine eiland Anguilla (Edwards-Gumbs, 2014).

\subsection{Aantrekken en behouden van leraren: individuele en contextuele factoren}

Om goed onderwijs te kunnen bieden zijn goed opgeleide, gemotiveerde en bekwame leerkrachten onmiskenbaar van belang (Cörvers, 2014). De werving van leraren moet dan ook worden gezien als essentieel voor iedere onderwijsinstelling en elk onderwijssysteem. De uitbreiding van het lerarenkorps in kwantitatieve zin kan echter ook ten koste gaan van de gemiddelde kwaliteit van het lerarenkorps, en zodoende een negatieve uitwerking hebben op de kwaliteit van het onderwijs. Voordat men begint met het werven van leerkrachten is het van belang om heldere en beknopte beschrijvingen te hebben van de vereiste vaardigheden en vakkennis van leerkrachten (Barber en Mourshed, 2007). Daarnaast moet worden vastgesteld waarom individuen willen worden aangeworven (Cockburn en Haydn, 2004). Individuen zullen een baan in het onderwijs accepteren wanneer het leraarschap wordt gezien als een aantrekkelijk beroep, in termen van salaris, werkomstandigheden en persoonlijke genoegdoening (Guarino et al., 2006).

\section{Beloning}

Vaak wordt de relatief lage beloning van leraren gezien als een factor die de aantrekkelijkheid van het beroep verkleint en het behoud van leraren tegenwerkt (Guarino et al., 2006; Wilson et al., 2004; Jules, 2008). De nadruk op het belang van lonen voor de werving sluit aan bij het neoklassieke economische migratiemodel waarin wordt aangenomen dat mensen zullen migreren voor een baan wanneer de lonen in een andere regio significant hoger liggen dan in de thuisregio. Voor de 
Engelstalige Caribische landen geldt inderdaad dat mensen doorgaans emigreren naar andere landen in hun streven naar betere salarissen en carrièremogelijkheden (Jules, 2008). Deze migratiebewegingen vormen kansen voor individuen, maar vormen tegelijkertijd een bedreiging voor kleine staten (zoals Anguila). Kleine staten blijken namelijk vaak niet in staat om baanopeningen die ontstaan door emigratie op te vullen met leraren die over de juiste kwalificaties beschikken (Jules, 2008).

Ladd (2007) stelt dat een beslissing van een individu om als leraar aan de slag te gaan en blijven niet enkel afhangt van het startsalaris, maar ook van de verwachte groei van het salaris over de tijd. Van belang is dus te kijken naar wat een potentiële leerkracht naar verwachting zal verdienen gedurende de gehele carrière als leerkracht, in vergelijking met andere beroepen. Dit is des te meer van belang gezien het gegeven dat op de Pacifische eilanden - en in verschillende andere landen ter wereld leraren gegarandeerd tewerkgesteld worden tot het moment van uittrede van de arbeidsmarkt wegens pensionering (Levine, 2013). De impliciete assumptie die hierbij gemaakt wordt, is dat het beroep van leraar aantrekkelijk voor het leven is.

In Indonesië zijn er verschillende onderzoeken gedaan naar de impact van de onderwijshervormingen van 2005 (Chang et al., 2014). Met deze hervormingen werd beoogd de kwaliteit en de aard van het primair en secundair onderwijs te verbeteren. Een unieke component van de doorgevoerde hervormingen is de verdubbeling van salarissen, welke volgde op certificering die verplicht doorlopen moest worden. De certificering bestond echter uit het doorlopen van een relatief lichte training (van ca. 90 uur) voor het bestaande lerarenkorps, met voorrang voor de leraren met senioriteit. Gaandeweg de hervorming werd de certificering steeds meer vervangen door het indienen van een portfolio van vaardigheden om het certificaat te verkrijgen. Het resultaat is vooralsnog dat leraren meer tevreden zijn met hun baan en minder financiële stress hebben, en dat de status van het beroep lijkt te zijn gestegen. Toch is er geen enkel effect waar te nemen op de testscores van leerlingen (De Ree et al., 2015). Hoewel Indonesië qua bevolkingsomvang (meer dan 124 miljoen mensen) geheel onvergelijkbaar is met Caribisch Nederland, bestaan er ook overeenkomsten, zoals de geografische spreiding, een cultureel zeer diverse populatie en een grote versnippering in het onderwijs (door bijvoorbeeld de verschillende religies en de verschillen tussen publieke en private scholen). Bovendien heeft Indonesië rurale en afgelegen gebieden, waar het aandeel scholen met lerarentekorten veel groter is en leerkrachten doorgaans lager geschoold zijn dan in de steden.

\section{Lerarenstatus}

Naast beloning kan de status van een beroep bijdragen aan de aantrekkelijkheid van een beroep. Vanuit de neoklassieke economische theorie kan ook hier worden beredeneerd dat de kans dat een individu zal kiezen voor het beroep van leraar zal toenemen naarmate de status van het lerarenberoep hoger is dan (of ten minste gelijk aan) de status van alternatieve beroepen. De status van een beroep is echter vaak diep geworteld en is de uitkomst van verschillende factoren, waaronder de vereiste onderwijskwalificaties, het salaris- of inkomensniveau, de competenties die vereist zijn wat betreft vakkennis en pedagogische vaardigheden. Ook spelen de motivatie om les te geven, de mate waarin leraren zijn toegewijd, en de officiële certificering een rol. De certificering is te beschouwen als een erkenning dat lesgeven wordt gezien als 'professie'. 
Indonesië heeft een aanzienlijke uitbreiding van het onderwijsstelsel doorgemaakt in de jaren '70 en '80, waardoor een zeer groot aantal nieuw opgeleide leerkrachten werd aangesteld. Het lesgeven werd daarop minder bezien als 'roeping', en het leraarschap werd niet zozeer beschouwd als een beroep van groot maatschappelijk belang, maar veeleer als een beroep met baanzekerheid, weinig eisen, korte werkuren en een baan voor het leven. Bovendien hadden veel leraren een tweede baan, was het verzuim hoog en de werkethiek onvoldoende. Samenvattend kan gesproken worden van een 'deprofessionalisering' van het beroep. De status van leraren was in Indonesië daardoor laag in vergelijking tot andere beroepen in Indonesië en met het beroep van leraar in de omliggende landen (Chang et al., 2014).

Professionele omstandigheden

Hoewel beloning (en daaraan gekoppelde status) een belangrijke factor is in het behouden van leraren, blijken leraren ook om heel andere redenen het beroep te verlaten. In de zoektocht naar baan- en carrièremogelijkheden door leraren is het van groot belang inzicht te krijgen in hun motivaties om van baan te wisselen of zelfs het onderwijs geheel te verlaten. De rol van leraren en de vereisten die aan leraren worden gesteld, zijn in de loop der jaren veranderd. Verwachtingen van leraren zijn toegenomen en hun takenpakket is uitgebreid. Om ervoor te zorgen dat deze veranderingen niet leiden tot het vertrek van leraren, moet volgens Bubb en Early (2007) aandacht worden besteed aan de arbeidsomstandigheden, het welzijn van het personeel en de motivatie voor het lesgeven. Wilson et al. (2004) voegen nog andere factoren aan dit rijtje toe, waaronder: mogelijkheden voor professionele groei, aangename omgeving, intellectuele uitdaging, adequate bronnen, ruimte voor creativiteit, vrijheid en interactie tussen collega's.

Sharplin (2002) voerde een kwalitatieve studie uit onder studenten van lerarenopleidingen, om zodoende inzicht te verkrijgen in hun verwachtingen omtrent remote teaching op zowel professioneel als persoonlijk en sociaal gebied. Studenten van lerarenopleidingen bleken slecht geïnformeerd te zijn over het lesgeven in afgelegen gebieden. Zij bleken uit te gaan van gebrekkige en eenzijdige stereotiepe ideeën over lesgeven op afgelegen scholen. Zij waren bijvoorbeeld bezorgd dat op dergelijke scholen te weinig ervaren leerkrachten rondlopen, en er een gebrek is aan mentoren (of toegang tot ervaren collega's). Dat er in de praktijk inderdaad nadelen worden ondervonden aan het werken in geïsoleerde gebieden bleek ook uit een enquête onder artsen in landelijke regio's van Brits-Columbia. Zij voelden zich geïsoleerd en afgezonderd van hun medische collega's. Deze 'professionele isolatie' woog nog zwaarder in hun besluit om terug te keren dan hun baantevredenheid en sociale isolatie. De belangrijke rol van de medische collega's (professionele gemeenschap) kan worden bezien in het licht van de migratietheorie over integratie, maar houdt ook verband met het werkklimaat en de arbeidsomstandigheden die in hoofdstuk 3 onder overige pullfactoren in de neoklassieke theorie van migratie zijn genoemd.

Lunn (1997, p. 48) benoemt verschillende barrières voor het behoud van leraren in rurale en afgelegen gebieden, waaronder de wens of noodzaak om terug te keren, het gebrek aan mogelijkheden tot professionele promotie en ontevredenheid met lesgeven of het leven in rurale, afgelegen gebieden. Volgens Lunn (1997) zijn er zes drempels bij het aantrekken van leraren naar landelijke gebieden. Hierbij is de specifieke context van waaruit geworven wordt (school in afgelegen, landelijk gebied) in ogenschouw genomen. De genoemde factoren hebben naast sociaalgeografische obstakels ( 3 en 4 ) betrekking op professionele groei $(1,2$ en 5 ) en privéfactoren ( 5 en 
6). Opvallend hierbij is dat beloning niet als zodanig genoemd is, hoewel dit mogelijk deel uitmaakt van een 'aantrekkelijke en rendabele carrière' (1).

Tabel 4.1

Zes drempels bij het aantrekken van leraren naar landelijke gebieden volgens Lunn (1997)

1. Een negatieve perceptie van lesgeven als een aantrekkelijke en rendabele carrière;

2. De betere arbeidsmarktperspectieven in stedelijke scholen in tijden van lerarentekorten, in het bijzonder voor vakspecifieke leraren;

3. De oververtegenwoordiging van studenten uit (voor-)stedelijke gebieden in lerarenopleidingen;

4. De afname van studentenaantallen uit landelijke en afgelegen gebieden bij de instroom in lerarenopleidingen;

5. De persoonlijke en professionele gedachtes van ervaren leraren, koppels in het bijzonder, die woonachtig zijn in grootstedelijke gebieden, dat overplaatsing naar afgelegen gebieden negatieve gevolgen zal hebben voor hun situatie en ontwikkeling (ontwrichting);

6. Het gebrek aan persoonlijke en professionele prikkels om een onderwijspositie in een afgelegen gebied aan te nemen.

Daarnaast is het begrip 'perceptie' belangrijk, omdat het denkbaar is dat de percepties van individuen met betrekking tot het leraarschap kunnen voortkomen uit een gebrek aan informatie en dus mogelijk te beïnvloeden zijn. Afhankelijk van de perceptie en de werkelijke situatie, kunnen er tegenover de genoemde drempels verschillende pullfactoren staan, zoals aantrekkelijke arbeidsvoorwaarden, een positieve perceptie van het leraarschap, goede arbeidsmarktperspectieven en voldoende professionele prikkels (bijvoorbeeld: meer verantwoordelijkheid, kennismaking met een nieuw curriculum en een toename van variatie in lesgeven). Bij het aantrekken en behouden van leraren is het niet enkel van belang om de push- en pullfactoren in kaart te brengen, maar ook te kijken naar het gewicht van de verschillende factoren.

\section{Privé-omstandigheden}

Naast professionele factoren kunnen er factoren op persoonlijk gebied spelen waardoor het al dan niet aantrekkelijk is voor individuen om alleen of samen met hun gezin in een afgelegen gebied te wonen en werken. Boylan en Bandy (1994) stellen dat mensen die het werken in afgelegen gebieden als uitdaging zien en daarbij de nadruk leggen op positieve, voordelige, persoonlijke en professionele aspecten van een landelijke levensstijl, van blijvende waarde zullen zijn voor de gemeenschap aldaar. Een enquête in Brits-Columbia ondersteunt deze opvatting met de bevinding dat leraren die blijven een hoge mate van baantevredenheid rapporteren, en aan ten minste één van de volgende twee kenmerken voldoen:

1. Zij hebben een stabiel gezinsleven waarbij er vaak sprake is van een professioneel koppel met beide partners werkzaam in het onderwijs;

2. Zij zijn 'sociaal actief' in de zin dat zij deel uitmaken van verenigingen en andere belangenorganisaties, met andere woorden actief betrokken zijn bij de gemeenschap. 
Om een inschatting te kunnen maken van welke leraren zullen blijven of vertrekken, is het dus van belang om naast professionele ambities aandacht te besteden aan privéfactoren, welke zowel op individueel niveau als op huishoudniveau of het niveau van de gemeenschap kunnen spelen. Dit is in overeenstemming met het huishoudperspectief in de nieuwe economische stroming van migratietheorieën, en met het in de integratietheorieën genoemde belang van sociale integratie voor baantevredenheid. Het behoud van leraren is mogelijk een nog grotere uitdaging in het geval van jonge leerkrachten dan in het geval van meer 'gevestigde' leerkrachten. Jongere leraren blijken immers doorgaans vaker van baan of beroep te wisselen dan oudere leraren (Loeb en Béteille, 2008). Wanneer het lerarenkorps in afgelegen gebieden overwegend jong is, zal het behouden van leerkrachten een des te grotere opgave zijn. Bovendien zijn bijvoorbeeld leraren in Australië behalve relatief jong, ook relatief vaak afkomstig uit blanke, stedelijke middenklasse-omgevingen en hebben zij weinig interactie met mensen van een andere etnische- of sociale achtergrond (Heslop, 2003). Het is denkbaar dat juist deze groep leraren op den duur te maken krijgt met (één of meerdere van) de eerdergenoemde onaantrekkelijke omstandigheden in de privésfeer, waarop zij zouden kunnen besluiten het leraarschap aldaar de rug toe te keren.

\subsection{Beleidsinstrumenten}

\section{Financiële prikkels}

Vanuit de neoklassieke economische theorie kan worden gesteld dat een verhoging van het salaris van een bepaald beroep zal leiden tot een groter aanbod van mensen voor dat beroep. Hoewel beloning in verschillende studies wordt gezien als belangrijke factor in de aantrekkelijkheid van een beroep, zijn de onderzoeksbevindingen hieromtrent niet eenduidig. Zo laat Feng (2009) zien dat het arbeidsaanbod van leraren in Florida relatief inelastisch is. Het verhogen van salarissen van leraren tot het niveau van salarissen in alternatieve beroepen (een toename van $12 \%$ ), zorgt volgens Feng (2009) voor een toename van slechts $0,48 \%$-punt in het behoud van leraren over een periode van zes jaar (van $82,12 \%$ naar $82,60 \%$ ).

In Indonesië hebben de professionalisering van het lerarenberoep en de verdubbeling van de salarissen van leraren echter wel degelijk geleid tot een verhoogde instroom van studenten in de lerarenopleidingen en een groeiend aanbod van afgestudeerden, inclusief meer academische opgeleide afgestudeerden. Bovendien is de kwaliteit van de instromers in de lerarenopleidingen in Indonesië verbeterd in de jaren na invoering van de Teacher and Lecturer Law in 2005, gericht op de hervorming van het schoolmanagement en de verbetering van de loopbaanontwikkeling van leraren. De testscores van studenten die kozen voor de lerarenopleiding zijn harder gestegen dan de testscores van studenten die instroomden in alternatieve opleidingen op hetzelfde niveau. Dat betekent dat er een beter potentieel aan kandidaten is voor de instroom in het lerarenberoep, waarmee de status van het beroep kan worden verhoogd. De certificering en loonsverhoging hebben echter (vooralsnog) niet geleid tot een verbetering van de vakkennis en pedagogische vaardigheden van leraren. Een grotere bekwaamheid onder de zittende leraren (Chang et al., 2014) kon niet worden aangetoond, ook niet aan de hand van testscores van de leerlingen op de scholen die een certificering van hun lerarenkorps hadden doorlopen.

Om de aantrekkelijkheid van het werken op scholen in afgelegen gebieden te vergroten, kan naast salarisverhogingen gedacht worden aan andere financiële prikkels. Een voorbeeld hiervan is het 
Northern and Rural Recruitment and Retention (NRRR) initiatief. ${ }^{7}$ Dit programma heeft als doel artsen aan te trekken en te behouden voor rurale gebieden in Brits-Columbia. Zij ontvangen (verspreid over vier jaar) een extra geldsom bovenop het gewone salaris bij een voltijdsaanstelling in een landelijke regio binnen Brits-Columbia. Evaluaties van dit programma laten zien dat de financiële prikkels effectief zijn in de werving van artsen. Het programma blijkt echter minder succesvol in het behouden van artsen voor de langere termijn (Sempowski, 2004).

\section{Werving-en selectiepraktijken}

Uit Amerikaans onderzoek (waaronder Staiger en Rockoff, 2010) blijkt dat het erg moeilijk is voor schoolleiders om (de meest) geschikte leraren aan het begin van hun carrière te selecteren. Significante kwaliteits- en prestatieverschillen tussen leraren komen namelijk pas aan het licht als ze langer in dienst zijn. Op basis van een simulatiemodel, waarin gezocht wordt naar een zo hoog mogelijke productiviteit van het lerarenkorps door selectie van beginnende leraren, kan worden gesteld dat het efficiënt is om elk jaar een grote pool van leraren in opleiding aan te stellen en hieruit gedurende de eerste jaren alleen de allerbesten te selecteren. Naast afstudeercijfers en scores op entreetoetsen zouden dergelijke rigoureuze selectieprocessen gebaseerd moeten zijn op vakkennis, leesvaardigheid, rekenvaardigheid en communicatievaardigheden en interviews ter beoordeling van motivatie, persoonlijkheid en gevoeligheid voor de behoeften van leerlingen. Behalve de selectie van hoogwaardige leerkrachten kunnen dergelijke selectieprocedures ertoe leiden dat het leraarschap een hogere beroepsstatus krijgt (Barber en Mourshed, 2007).

Om de juiste kandidaten te vinden voor aanstellingen op scholen in afgelegen gebieden is door het departement van opleiding en scholing in het noordelijk gebied in Australië vastgesteld welke persoonlijke kenmerken vereist zijn voor een dergelijke aanstelling. Middels een mediacampagne werden leraren opgeroepen om online te solliciteren. ${ }^{8}$ Voorts werden er persoonlijkheidsprofielen opgesteld en werden kandidaten onderworpen aan een groepsassessment. Dit laatste selectieinstrument bleek het meest bepalend in het vaststellen van de geschiktheid van de kandidaten op basis van de volgende drie criteria: culturele sensitiviteit, het vermogen om te overtuigen en beïnvloeden en het vermogen om relaties op te bouwen. Deze drie criteria kunnen worden gevangen door de termen 'sociaal en cultureel kapitaal', welke naast menselijk (pedagogisch) kapitaal een belangrijke rol spelen in het succesvol invullen van het leraarschap op afgelegen scholen. De gebruikte mediacampagnes zijn een voorbeeld van een actieve wervingscampagne om, voor de beste schoolverlaters van het middelbaar onderwijs en voor goede kandidaten die een carrièreswitch willen maken, uit te dragen dat het lerarenberoep een betekenisvol beroep is.

Lyday et al. (1990) en McSwan en Stevens (1995) stellen in aansluiting daarop dat leraren die zelf afkomstig zijn uit landelijke gebieden eerder kiezen voor het leraarschap in afgelegen gebieden, en dat zij bovendien een grotere kans hebben om daar ook te blijven. Op basis van hun bevindingen kan worden beargumenteerd dat lerarenopleidingen moeten investeren in het aantrekken van studenten afkomstig uit landelijke gebieden. Bovendien stellen Boylan en Bandy (1994) dat

\footnotetext{
${ }^{7}$ http://www.health.gov.on.ca/en/pro/programs/northernhealth/nrrr.aspx

8 Belangrijk hierbij is dat het wervingsproces geheel geframed was met een nadruk op de privileges voor leraren. Hiermee moesten de sollicitanten het gevoel krijgen dat hen een unieke kans geboden werd, en werd de suggestie voorkomen dat scholen moeite hebben bij het aantrekken van voldoende gekwalificeerde leerkrachten.
} 
selectiepraktijken gericht zouden moeten zijn op leraren met een rurale achtergrond en met specifieke karakteristieken en onderwijservaring die maken dat zij zich permanent vestigen in ruraal gebied. Ook voor personeel in de gezondheidszorg in zowel lage- als hogelonenlanden blijkt opgroeien in een ruraal gebied een positief effect te hebben op de kans om later ook in ruraal gebied een baan aan te nemen (zie het literatuuroverzicht van Lehmann et al., 2008).

In aanvulling op bovengenoemde selectiepraktijken stellen Barber en Mourshed (2007) meer flexibele benaderingen voor bij het opleiden van leraren, zoals de mogelijkheid tot parttime studeren en studeren op afstand, in het bijzonder voor onconventionele kandidaten van ondervertegenwoordigde groepen zoals etnische minderheiden, mensen met lichamelijke beperkingen, en mannen in het basisonderwijs. Daarnaast kan het bieden van een duidelijk carrièreperspectief, met de mogelijkheid tot promotie binnen het lerarenberoep, de selectie van potentieel hoogwaardige leerkrachten vergroten.

\section{Pre-service teaching programs}

De kloof die volgens Sharplin (2002) bestaat tussen verwachtingen van leraren omtrent werken op afgelegen scholen en de werkelijkheid, kan overbrugd (of bevestigd) worden door leraren in hun opleiding (vroegtijdig) kennis te laten maken met het lesgeven in afgelegen gebieden. Dergelijke strategieën zijn op verschillende plaatsen ter wereld geïmplementeerd. Voorbeelden zijn hoofzakelijk in Australië te vinden (Jorgensen et al., 2010; Yarrow et al., 1999). In de meeste gevallen is hiertoe gebruik gemaakt van speciale modules binnen de lerarenopleiding, waarbij studenten voor een bepaalde tijd stage liepen op een school in een ruraal gebied om zodoende ervaring op te doen in het lesgeven op deze scholen en het leven in een landelijke omgeving.

In Australië zijn in het kader van het TERRAnova project (Teacher Education for Rural en Regional Australia) wervingsstrategieën opgesteld, waarmee wordt beoogd leraren in opleiding kansen te bieden en aanstellingen in ruraal gebied te stimuleren (Munsch en Boylan, 2008). Voorbeelden zijn Beyond the line en het Enhanced Teacher Training Scholarship Program. Ondanks de focus op lesgeven in regionale gemeenschappen door middel van stages, richten universiteiten in Australië zich in de voorbereiding van hun studenten hoofdzakelijk op het eigen geografische bereik. Hierdoor worden de meest succesvolle studenten met een sterke sociale motivatie in de meerderheid van de gevallen aangesteld op scholen in de eigen staat en niet in afgelegen gebieden. Bovendien blijkt dat studenten in de meeste gevallen niet starten met lesgeven op de school waar zij in het kader van het genoemde Enhanced Teacher Training Scholarship Program stage hebben gelopen.

Er zijn verschillende studies naar de effectiviteit en het succes van programma's waarin leraren in opleiding ervaring opdoen in het werken en wonen in afgelegen gebieden met het zicht op tewerkstelling in een dergelijke omgeving (Ballantyle en Mylonas, 2001; Gibson, 1994; Munsch en Boylan, 2008). Waar Sharplin (2002) enkel laat zien dat studenten in lerarenopleidingen er negatieve stereotyperingen op nahouden wanneer zij geen 'rural practicum' ondergaan, tonen Musch en Boylan (2008) aan dat kennis en begrip omtrent rurale scholen en samenlevingen zich positief ontwikkelen als gevolg van praktijkervaring aldaar. De keerzijde hiervan is natuurlijk dat een stage ook kan leiden tot de bevestiging van bestaande (negatieve) vooroordelen. Deze uitkomst van de 'try-before-you-buy' benadering is echter niet per se negatief; niet alle leraren (in opleiding) zijn immers geschikt om les te geven aan scholen in geografisch geïsoleerde gebieden (Brasche en Harrington, 2012). 
Omdat de vertrekredenen van leraren vaak te maken hebben met onaantrekkelijke werkomstandigheden, stelt Edwards-Gumbs (2014) voor Anguila een aantal maatregelen voor die de aantrekkelijkheid van het beroep moeten vergroten. Zo stelt hij een intensivering voor van de connectie tussen schoolbesturen en het Ministerie van Onderwijs, waarbij schoolbesturen en leraren meer ondersteuning ontvangen. Betere werkomstandigheden, goed leiderschap en sterk management moeten ervoor zorgen dat het beroep van de leraar in een positiever daglicht komt te staan (Edwards-Gumbs, 2014). Ook zouden er meer mogelijkheden moeten worden geboden voor opwaartse mobiliteit en professionele ontwikkeling. Wat dat laatste betreft noemt hij het geven van constructieve feedback door leraren onderling en het praten over baantevredenheid, motivatie en werkdruk.

Of professionalisering van de onderwijssector inderdaad een positieve uitwerking heeft op de motivatie, baantevredenheid en behoud van leraren, moet nader worden onderzocht. Uitgaande van de vaststelling van Ingersoll en Merill (2011) dat de mate van professionalisering doorgaans sterk verschilt tussen scholen, kan de samenhang tussen professionaliteit en lerarenbehoud worden onderzocht door scholen te classificeren en met elkaar te vergelijken. Volgens de Onderwijsraad (2013) bestaat het geven van professionele ruimte aan leraren eruit dat zij zelf een visie ontwikkelen op onderwijskwaliteit, lesmateriaal ontwikkelen en betrokken zijn bij het praktijkgericht onderzoek naar de evaluatie van de door hen doorgevoerde veranderingen in de onderwijsinhoud en het onderwijsproces. Dit zou ten goede kunnen komen aan de kwaliteit van het onderwijs, de aantrekkelijkheid van het werk en de ontwikkelmogelijkheden binnen de loopbaan. Juist voor afgelegen gebieden lijkt het zinvol om een beroep te doen op leraren die de professionele ruimte goed kunnen invullen.

Vermeulen (2012) stelt dat de ruimte die leraren van schoolleiders krijgen om zich te ontwikkelen afhankelijk lijkt te zijn van de kwaliteit van deze leraren, waarbij een kwaliteitstekort onder leraren juist meer inkadering van de lesmethodes en meer toezicht vereisen. Zowel een adequate aansturing en goed leiderschap door schoolleiders als hoogopgeleide, vakbekwame leraren zijn nodig om de professionele ruimte van leraren optimaal te benutten. Juist op veel scholen in Caribisch Nederland bestaat het risico dat aan deze voorwaarden onvoldoende wordt voldaan. De Onderwijsraad (2013) oordeelt dat het benutten van de professionele ruimte samen dient te gaan met "verantwoordelijkheid nemen en verantwoording afleggen". Aangezien er tot op heden geen harde effectevaluaties bekend zijn van een betere benutting van de professionele ruimte, is het gewenst dat dergelijk onderzoek wordt uitgevoerd om het rendement van projecten op dit gebied te kunnen beoordelen, en waar nodig het professionaliseringsbeleid te optimaliseren.

\section{Inductie- en mentorprogramma's}

Een hoog lerarenverloop is niet louter negatief: het kan eveneens worden gezien als een goede strategie om de beste leraren te behouden en daarmee prestaties van leerlingen positief te beïnvloeden. Toch is er groeiende consensus over de kosten van dit verloop. Leraren zijn waardevolle bronnen gezien de investeringen in opleiding en werving, en nieuwkomers doen het vaak minder goed dan de meer ervaren leerkrachten. Van belang is verder dat verschillende studies aantonen dat een snelle evaluatie van leraren in combinatie met de beëindiging van contracten van nieuwe leraren (vroeg in hun carrière) de meest kosteneffectieve manier is om het leerproces van 
leerlingen te verbeteren (Staiger en Rockhoff, 2010). Andere studies laten zien dat juist de beter gekwalificeerde leraren (niet noodzakelijkerwijs de meer effectieve leraren) een grotere kans hebben om te stoppen met lesgeven, tenminste in bepaalde regio's (Loeb en Reininger, 2004).

Als gevolg van de hoge kosten van het verloop van leraren zijn er verschillende inductie- en mentorprogramma's ontwikkeld en op grote schaal ingevoerd. Deze programma's zijn gericht op (jonge) beginnende onderwijzers met als doel de 'slaagkansen' van deze beginnende leraren te vergroten en de kans op uittrede te verkleinen. Bestaande onderzoeken naar de effecten van dergelijke programma's concluderen over het algemeen dat inductie- en mentorprogramma's een positieve invloed hebben (Ingersoll en Strong, 2011). Zo laten leraren die hebben deelgenomen aan een dergelijk programma een grotere tevredenheid, toewijding of kans op behoud zien. Tegelijkertijd laten verschillende studies zien dat beginnende leerkrachten die deelnemen aan een inductie- of mentorprogramma beter presteren op verschillende aspecten van het lesgeven. Ook de leerprestaties van leerlingen zijn beter wanneer beginnende docenten deelnemen aan een of andere vorm van inductieprogramma. Wat betreft het lesgeven in afgelegen, geïsoleerde gebieden zouden introductie- en mentorprogramma's in het bijzonder bijdragen aan het overwinnen van het gevoel van isolatie, de vergroting van veiligheidsgevoel in de gemeenschap, en de ontwikkeling van professionele vaardigheden. In een studie van Boylan en Bandy (1994) is een positieve invloed gevonden van 'sociale integratie' in de gemeenschap op de bereidheid van beginnende leraren om te blijven. 


\section{Conclusie}

Deze studie biedt middels een literatuuronderzoek inzicht in de problematiek van de arbeidsmarkt van leraren in het primair onderwijs, het voortgezet onderwijs en het middelbaar beroepsonderwijs op Caribisch Nederland. De centrale vraag hierbij is welke factoren bijdragen aan het aantrekken en behouden van hoogwaardige leerkrachten op de BES-eilanden. Op basis van beschrijvingen en analyses van vergelijkbare problematiek in de wetenschappelijke literatuur en in beleidsdocumenten is nagegaan wat de 'best practices' zijn om om te gaan met de personeelsvoorziening (van leraren) en de grote dynamiek wat betreft in- en uitstroom op de (onderwijs)arbeidsmarkt van en naar de BES-eilanden. De studie biedt tevens handvatten voor een verdiepend veldonderzoek onder beoefenaars van het lerarenberoep en potentiële leerkrachten, naar de motivatie van de keuze voor het leraarschap (in Caribisch Nederland), en de motivatie om al dan niet als leraar (aldaar) te blijven werken met het vorderen van de loopbaan.

Om het potentiële aanbod van leraren op de BES-eilanden te kunnen vergroten is inzicht in de verschillende push- en pullfactoren noodzakelijk. Wat betreft de situatie op de BES-eilanden is het belangrijk om na te gaan of de salarissen van leraren competitief zijn met deze in andere beroepen, of met salarissen van leraren in landen met potentieel aanbod. ${ }^{9}$ Bovendien zal moeten worden achterhaald of het leraarschap al dan niet wordt beschouwd als beroep voor het leven en hoeverre de loonontwikkeling hierin een rol speelt. Ook is het belangrijk om voor de arbeidsmarkt in Caribisch Nederland inzicht te krijgen in de status van het lerarenberoep en hoe zich deze verhoudt tot overige beroepen. In de bestaande literatuur wordt er naast aandacht voor aantrekkingsfactoren op individueel niveau, zoals een (relatief) hoog salaris en een (daaraan gekoppelde) hoge status, ook aandacht besteed aan professionele kenmerken van het leraarschap. In bestaande case studies wordt doorgaans impliciet uitgegaan van de neoklassieke economische (migratie-)theorie, waarbij een individu (of: huishouden zoals binnen het nieuwe economische model van arbeidsmigratie) streeft naar een situatie die zoveel mogelijk tegemoet komt aan zijn behoeften, zoals inkomen en baanzekerheid. De uiteindelijke beslissing om van baan te wisselen hangt af van de verhouding tussen (verwachte) kosten of risico's en (verwachte) opbrengsten van de verschillende opties.

Voor de aantrekkelijkheid van het lerarenberoep in Caribisch Nederland - in termen van bijvoorbeeld salaris en loonontwikkeling, status, secundaire arbeidsvoorwaarden - is het van belang te weten hoe deze zich verhoudt tot alternatieve beroepen of het lerarenberoep in andere landen. Voor zowel zittend onderwijzend personeel als voor potentiële leerkrachten spelen push- en pullfactoren een rol. Naast de 'harde' factoren omtrent arbeidsvoorwaarden, moet worden nagegaan in hoeverre 'softere' factoren zoals werkomstandigheden, mogelijkheden voor professionele groei, een aangename omgeving, intellectuele uitdaging, adequate bronnen, ruimte voor creativiteit, vrijheid en interactie tussen collega's, een rol spelen bij het aantrekken en/of behouden van leerkrachten voor de arbeidsmarkt in Caribisch Nederland.

Bestaand onderzoek naar de lerarenarbeidsmarkt in afgelegen gebieden laat zien dat studenten uitgaan van gebrekkige, eenzijdige en stereotiepe ideeën bij het lesgeven op afgelegen scholen (Sharplin, 2002). Hiermee wordt duidelijk dat push- en pullfactoren lang niet in alle gevallen gebaseerd zijn op objectief verkregen informatie. Bovendien blijken naast werkgerelateerde

\footnotetext{
${ }^{9}$ Waarbij gecorrigeerd dient te worden voor verschillen in kosten voor levensonderhoud.
} 
aspecten, privéfactoren een belangrijke invloed te hebben op het behoud van leerkrachten. Leraren die sterk sociaal geïntegreerd zijn in de gemeenschap waar zij lesgeven, leraren met een stabiel gezinsleven en leraren die de landelijke levensstijl positief waarderen, hebben een grotere kans om tevreden te zijn met hun baan in een afgelegen gebied. Om een inschatting te kunnen maken van welke leraren zullen blijven of vertrekken is het dus van belang om naast professionele ambities ook aandacht te besteden aan privéfactoren, welke zowel op individueel niveau als op huishoudniveau of het niveau van de gemeenschap van belang kunnen zijn.

Er bestaan verschillende beleidsinstrumenten die gericht zijn op het aantrekken en behouden van hoogwaardige leerkrachten. Zo is er op verschillende plekken ter wereld geëxperimenteerd met financiële prikkels teneinde de instroom in specifieke beroepen te vergroten, evenals met selectie op de kwaliteit van het aanbod. In Indonesië heeft de verplichte certificering van leraren in combinatie met een verdubbeling van de beloning geleid tot een flinke toename van studenten in lerarenopleidingen. Bovendien bleek voor dit land dat na de invoering van de Teacher and Lecturer Law (2005), teneinde het schoolmanagement en de werving en professionele ontwikkeling van leraren in Indonesië radicaal te hervormen, de instroom in de lerarenopleidingen - afgaande op de testscores - van een hoger niveau dan in de jaren ervoor. Betere kandidaten worden aangetrokken tot het lerarenberoep, waarmee de status van het beroep werd verbeterd. De toenemende instroom en selectie van betere leerlingen (gebaseerd op testscores) heeft zich daar echter nog niet vertaald in verhoogde vakkennis van leraren of de kwaliteit van het lesgeven.

Wanneer men overweegt om financiële prikkels te introduceren (bijvoorbeeld een loonsverhoging) moet altijd worden nagegaan wie hiermee worden aangetrokken, waarmee het belang van goede selectieprocedures wordt onderstreept. Naast vakkennis en pedagogische vaardigheden moet daarbij gekeken worden naar de motivatie en toewijding van de leraar (in opleiding) en het bezit van culturele sensitiviteit, het vermogen om te overtuigen en beïnvloeden, en het vermogen om relaties op te bouwen. Met het oog op beleid van leerkrachten in afgelegen gebieden, kan actieve werving het beste worden gericht op leraren die zelf afkomstig zijn uit landelijke gebieden. Zij kiezen eerder voor het leraarschap in afgelegen gebieden en hebben bovendien een grotere kans om daar ook te blijven (Lyday et al., 1990; McSwan en Stevens, 1995).

Vooroordelen over lesgeven in afgelegen, landelijke gebieden, kunnen mogelijk worden weggenomen door leraren in opleiding kennis te maken met het lesgeven aldaar. Kennis en begrip omtrent rurale scholen en samenlevingen blijkt zich positief te ontwikkelen als gevolg van praktijkervaring tijdens de opleiding (Boylan, 2008). Bovendien kan op deze manier vroegtijdig de selectie van de beste en/of meest geschikte leraren plaatsvinden, wat de kwaliteit en status van de leraren ten goede zal komen. Daarnaast kan worden gedacht aan andere manieren voor de verdere professionalisering van het onderwijs. Een voorbeeld hiervan is het vergroten van de professionele ruimte die leraren van schoolleiders krijgen om zich te ontwikkelen. Andere instrumenten om de kwaliteit van leraren te verhogen zijn inductie- en mentorprogramma's, met als doel de slaagkansen van beginnende leraren te vergroten en de kans op uittrede te verkleinen. Deze programma's blijken zowel op professioneel gebied als in de privésfeer (integratie in de sociale context) positieve effecten te kunnen voortbrengen.

Samengevat kan de relatie tussen migratiestromen en het HRM-beleid van scholen wat betreft werving, selectie en behoud van leraren worden weergegeven als in tabel 5.1. Het HRM-beleid van 
scholen is vooral van belang wanneer de invulling van vacatures door leraren moeilijk verloopt, dat wil zeggen als de knelpunten in de personeelsvoorziening groot zijn. Juist in de afgelegen gebieden is het vaak moeilijk om de vacatures voor leraren in te vullen, waardoor het HRM-beleid door werkgevers vooral in deze gebieden van groot belang is.

Tabel 5.1

Push- en pullfactoren bij migratie en belangrijke factoren in het HRM-beleid van scholen

\begin{tabular}{|c|c|}
\hline $\begin{array}{l}\text { Push- en pullfactoren van migratie tussen } \\
\text { landen en gebieden }\end{array}$ & $\begin{array}{l}\text { Factoren in HRM-beleid van belang bij } \\
\text { migratiebeslissingen naar afgelegen gebieden }\end{array}$ \\
\hline $\begin{array}{l}\text { 1. Economische theorie } \\
\text { Arbeidsvoorwaarden: salaris, contractduur, } \\
\text { arbeidsduur } \\
\text { Status: economisch en sociaal (imago) } \\
\text { Huishoudsituatie: (werkende) partner, } \\
\text { (schoolgaande) kinderen }\end{array}$ & $\begin{array}{l}\text { - } \text { Financiële prikkels } \\
\text { - Maatwerk arbeidsvoorwaarden } \\
\text { - Professionaliseringsbeleid }\end{array}$ \\
\hline $\begin{array}{l}\text { 2. Roltraptheorie } \\
\text { Levensfase: studie, werk, gezinsvorming } \\
\text { Regiokenmerken: urbanisatiegraad, } \\
\text { voorzieningen }\end{array}$ & $\begin{array}{l}\text { - Inductie- en mentorprogramma's } \\
\text { - Werving en selectie }\end{array}$ \\
\hline $\begin{array}{l}\text { 3. Netwerktheorie } \\
\text { Migrantennetwerken: sociaal kapitaal, } \\
\text { positieve en negatieve signalen vanuit } \\
\text { migrantengemeenschap }\end{array}$ & $\begin{array}{l}\text { Voorlichting over werken in afgelegen } \\
\text { gebieden }\end{array}$ \\
\hline $\begin{array}{l}\text { 4. Sociologische theorie } \\
\text { Sociale cohesie en integratie: aanwezigheid } \\
\text { van dezelfde etnische groepen, integratie } \\
\text { in gemeenschap }\end{array}$ & $\begin{array}{l}\text { - Pre-service teaching programs (voor } \\
\text { afgelegen gebieden) }\end{array}$ \\
\hline
\end{tabular}




\section{Referentielijst}

Ballantyne, R. en Mylonas, A. (2001). Improving Student Learning During 'Remote' School-based Teaching Experience Using Flexible Delivery of Teacher Mentor and Student Preparation Programmes, Asia-Pacific Journal of Teacher Education, 29(3), 263-273.

Barber, M. en Mourshed, M. (2007). How the World's Best Performing School Systems Come Out on Top, Study report, McKinsey en Company, New York.

Bauer, T., Epstein, G.S., Gang, L.N. (2000). What Are Migrant Networks? Bonn: IZA, Discussion Paper 200.

Beine, M., Docquier, F., Rapoport, H. (2008). Brain Drain and Human Capital Formation in Developing Countries: Winners and Losers. Economic Journal, 118(528), 631-652.

Boylan, C. en Bandy, H. (1994). Education and Training for Rural Teachers and Professionals. In: Issues Affecting Rural Communities. Proceedings of an International Conference Held by the Rural Education Research and Development Centre, Townsville, Queensland, Australia, July 10-15, 1994.

Boylan, C. en McSwan, D. (1998). Long-staying rural teachers: Who are they? Australian Journal of Education, 42(1), 49-65.

Brasche, I. en Harrington, I. (2012). Promoting teacher quality and continuity: Tackling the disadvantages of remote Indigenous schools in the Northern Territory. Australian Journal of Education, 56(2), 110-125.

Brown, D.L. (2002). Migration and Community: Social Networks in a Multilevel World. Rural Sociology, 67(1), 1-23.

Bubb, S. en Earley, P. (2007). Leading and Managing Continuing Professional Development (2nd ed), London, Paul Chapman.

Castles, S. en Miller, M.J. (2003). The Age of Migration: International Population Movements in the Modern World, New York: The Guilford Press.

CBS (2014a). Arbeidskrachten Onderzoek Caribisch Nederland 2014. Heerlen: CBS.

CBS (2014b). Internet-publicatie: Arbeidsparticipatie (15 tot 75 jaar) op Caribisch Nederland (maatwerk).

Champion, T. (2012). Testing the return migration element of the 'escalator region' model: an analysis of migration into and out of south-east England, 1966-2001. Cambridge Journal of Regions, Economy and Society, 5, 255-269.

Chang, M.C., Al-Samarrai, S., Ragatz, A.B., Shaeffer, S., De Ree, J., Stevenson, R. (2013). Teacher reform in Indonesia: the role of politics and evidence in policy making. World Bank Publications. Washington D.C.

Cockburn, A. en Haydn, T. (2004). Recruiting and retaining teachers: Understanding why teachers teach. Psychology Press. 
Conradson, D., en Latham, A. (2005). Escalator London? A case study of New Zealand tertiary educated migrants in a global city. Journal of Contemporary European Studies, 13(2), 159-172.

Cörvers, F. (2014). De arbeidsmarkt voor leraren: theorie, beleid en werkelijkheid. TPEdigitaal, 8(4), 132-149.

Cörvers, F., Claessen, J., Kluijfhout E. (2015). Vooronderzoek, Onderwijsarbeidsmarkt en lerarenopleidingen op Caribisch Nederland. ROA-TR-2015/2, Maastricht: Researchcentrum voor Onderwijs en Arbeidsmarkt.

De Ree, J., Muralidharan, K., Pradhan, M., Rogers, H. (2015). Double for Nothing? Experimental Evidence on the Impact of Unconditional Teacher Salary Increase on Student Performance in Indonesia, Working Paper 21806, National Bureau of Economic Research, 1050 Massachusetts Avenue Cambridge, MA 02138, December.

Dustmann, C. (2008). Return migration, investment in children, and intergenerational mobility: Comparing sons of foreign- and native-born fathers. Journal of Human Resources 43(2), 299-324.

Edwards-Gumbs, O. (2014). Anguilla: The Challenges of Teacher Recruitment. In: E. Thomas, Education in the Commonwealth Caribbean and Netherlands Antilles, London/New York: Bloomsbury Academic, 11-25.

Epstein, G.S. (2008). Herd and network effects in migration decision-making. Journal of Ethnic and Migration Studies, 24(4), 567-583.

Feng, L. (2009). Opportunity, Wages, classroom characteristics, and teacher mobility. Southern Economic Journal, 75(4), 1165-1190.

Fielding, A.J. (1992). Migration and social mobility: south east England as an escalator region. Regional Studies, 26(1), 1-15.

Gibson, I.W. (1994). Policy, practice and need in the professional preparation of teachers for rural teaching. Journal of Research in Rural Education, 10(1), 68-77.

Haug, S. (2008). Migration networks and migration decision-making. Journal of Ethnic and Migration Studies, 34(4), 585-605.

Heslop, J. (2003). Living and teaching in Aboriginal communities. In: Q. Beresford en G. Partington (Eds.), Reform and resistance in Aboriginal education. Crawley, Western Australia: University of Western Australia Press, 208-237.

Ingersoll, R.M., en Strong, M. (2011). The impact of induction and mentoring programs for beginning teachers a critical review of the research. Review of Educational Research, 81(2), 201-233.

Inspectie van het Onderwijs (2014). Onderwijsverbetering in Caribisch Nederland: het onderwijs op Bonaire, Sint Eustatius en Saba, die jaar na 10 oktober 2010. Utrecht: Inspectie van het onderwijs, Ministerie van Onderwijs, Cultuur en Wetenschap.

Jorgensen, R., Grootenboer, P., Niesche R., Lerman, S. (2010). Challenges for teacher education: the mismatch between beliefs and practice in remote Indigenous contexts. Asia-Pacific Journal of Teacher Education, 38(2), 161-175. 
Jules, D. (2008). Rethinking education for the Caribbean: A radical approach. Comparative Education, 44(2), 203-214.

Ladd, H.F. (2007). Teacher labor markets in developed countries. The Future of Children, 17(1), 201217.

Levine, V. (2013). Eduction in Pacific Island States. Pacific Islands Policy. East-West Center.

Lock, G., Reid, J., Green, B., Hastings, W., Cooper, M., White, S. (2009). Researching rural-regional (teacher) education in Australia. Education in Rural Australia, 19(2), 31-44.

Loeb, S. en Reininger, M. (2004). Public Policy and Teacher Labor Markets: What We Know and Why it Matters. The Education Policy Center at Michigan State University.

Loeb, S., en Beteille, T. (2008). Teacher labor markets and teacher labor market research. In G. Duncan \& J. Spillane (Eds.), Teacher Quality: Broadening and Deepening the Debate, Northwestern University.

Lunn, S. (1997). Rural strategies project. Brisbane: Priority Country Area Program.

Lyday, J.W. (1990). Rural high school students' interest in teaching as a profession. Rural Educator, 11(2), 17-19.

Massey, D., Arango, S.J., Hugo, G., Kouaouci, A., Pellegrino, A., Taylor, J.E. (1993). Theories of International Migration: a Review and Appraisal. Population and Development Review, 19(3), 431466.

McSwan, D. en Stevens, K. (1995). Post secondary school educational and vocational issues facing families in rural north Queensland: a report on research in progress. Education in Rural Australia, 5(1), 45-49.

Ministerie van OCW (2011). Onderwijsagenda voor Caribisch Nederland: samen werken aan kwaliteit. Den Haag.

Mountford, A. (1997). Can a brain drain be good for growth in the source economy? Journal of Development Economics, 53(2), 287-303.

Munsch, T.R., en Boylan, C.R. (2008). Can a Week Make a Difference? Changing Perceptions about Teaching and Living in Rural Alaska. Rural Educator, 29(2), 14-23.

Onderwijsraad (2013). Kiezen voor kwalitatief sterke leraren. Advies aan het Ministerie van OCW. Den Haag.

Sempowski, I.P. (2004). Effectiveness of financial incentives in exchange for rural and underserviced area return-of-service commitments: systematic review of the literature. Canadian Journal of Rural Medicine, 9(2), 82-88.

Sharplin, E. (2002). Rural retreat or outback hell: Expectations of rural and remote teaching. Issues in Educational Research, 12(1), 49-63.

Sjaastad, L.A. (1962). The costs and returns of human migration. The Journal of Political Economy, 70(5), 80-93. 
Skeldon, R. (1990). Population Mobility in Developing Countries: A reinterpretation. London: Bellhaven Press.

Staiger, D.O., Rockoff, J.E. (2010). Searching for Effective Teachers with Imperfect Information. Journal of Economic Perspectives, 24(3), 97-118.

Stark O. (1978). Economic-Demographic Interactions in Agricultural Development: The Case of Ruralto-Urban Migration. Rome: FAO.

Stark, O., Helmenstein, C., Prskawetz, A. (1997). Brain gain with a brain drain. Economics Letters, 55 (2), 227-234.

UNDESA (United Nations Department of Economic and Social Affairs) (2004). World economic and social survey 2004: international migration, pp 5:

http://www.un.org/en/development/desa/policy/wess/wess archive/2004wess part2 eng.pdf accessible: 8 August 2015.

Vermeulen, M. (2012). Lerarenbeleid 2.0. Tilburg: IVA beleidsonderzoek en advies.

Williams, J.D., en Sofranko, A.J. (1979). Motivations for the inmigration component of population turnaround in nonmetropolitan areas. Demography, 16(2), 239-255.

Wilson, S.M., Bell, C., Galosy, J.A., Shouse, A.W. (2004). "Them That's Got Shall Get": Understanding Teacher Recruitment, Induction, and Retention. Yearbook of the National Society for the Study of Education, 103(1), 145-179.

Yarrow, A., Ballantyne, R., Hansford, B., Herschell, P., Millwater, J. (1999). Teaching in rural and remote schools: A literature review. Teaching and Teacher Education, 15(1), 1-13. 